\title{
A Novel Geotechnical/Geostatistical Approach for Exploration and Production of Natural Gas from Multiple Geologic Strata
}

\author{
Quarterly Report \\ April - June 1996
}

Work Performed Under Contract No.: DE-AC21-89MC26026

For

U.S. Department of Energy

Office of Fossil Energy

Morgantown Energy Technology Center

P.O. Box 880

Morgantown, West Virginia 26507-0880

By

College of West Virginia

P. O. Box AG

Beckley, West Virginia 25802-2839

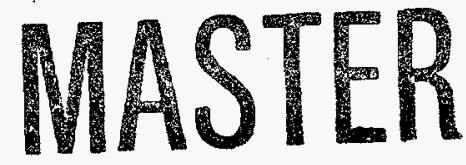

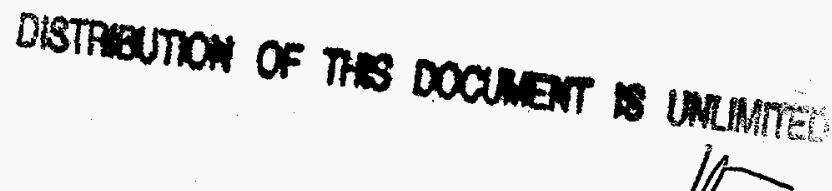




\section{Disclaimer}

This report was prepared as an account of work sponsored by an agency of the United States Government. Neither the United States Government nor any agency thereof, nor any of their employees, makes any warranty, express or implied, or assumes any legal liability or responsibility for the accuracy, completeness, or usefulness of any information, apparatus, product, or process disclosed, or represents that its use would not infringe privately owned rights. Reference herein to any specific commercial product, process, or service by trade name, trademark, manufacturer, or otherwise does not necessarily constitute or imply its endorsement, recommendation, or favoring by the United States Government or any agency thereof. The views and opinions of authors expressed herein do not necessarily state or reflect those of the United States Government or any agency thereof. 


\section{DISCLAMMIR}

Portions of this document may be illegible in electronic image products. Images are produced from the best available original document. 
PROGRESS AND ACHIEVEMENTS

A. SUMMARY OF TASK ACTIVITIES

10.0 ALASKAN ENERGY DEVELOPMENT

A Stop Work Order was issued for this Task by DOE, and the remaining Task 10 funds were reassigned to Tasks 12 and 13 .

\subsection{DEWATERING/PRODUCTION EXTENSION TEST PERIOD}

APRIL

Total gas production for the CWV system averaged 47.3 mcf per day on the rotary master meter and 50.3 on the orifice meter. The compressor was down for more than twelve days due mainly to Columbia shutdowns and a broken compressor coil. Line discharge pressure increased an average 10 pounds over last month because of numerous shut-ins and hotter weather.

TW1 averaged $43.1 \mathrm{mcf}$ per day from the Big Lime/Ravencliff formations and $3.7 \mathrm{mcf}$ per day from the coals. Once water production measurements were re-initiated with good weather, water production quickly stabilized. Water production from the coals consistently averaged 11.6 barrels per day as it has for some time. Field suction pressure obviously varied widely due to numerous shut-in periods. The pump system had 0 down days for the month.

TW2 showed a slight increase with an average of $8.5 \mathrm{mcfd}$. TW3 averaged 10 mcf per day from the coals. Water production remained consistent at 1.6 barrels per day, with 0 pump system down days. There was still no gas production from TW4 despite numerous adjustments to the pumping rate and schedule.

The large coil unit on the front of the compressor broke during April and was repaired on site by the well tender and a welder within a few days. Ladders were also placed onto the four water/brine storage tanks at each well site. 
Meetings were attended by CWV personnel April 15 - 17. The April 15 meeting was conducted at METC with Mahtav Gati, John Ganz, John Maestas, Linda Hawkins, and Ron Brunk. This meeting concerned the status of Tasks 10, 11 and 12. Ron Brunk attended the Coalbed Methane Meetings in Pittsburgh on April 16 and 17.

Also during April, the First Draft of the Addendum to the Project's Final Report was completed and delivered to DOE on April 15. This addendum covered the gas and water production data, as well as other field activities for the production phase of the Project (October 1992 - December 1995).

\section{$M A Y$}

Gas production increased for the month, averaging 58.9 mcf per day on the rotary master meter and $58.3 \mathrm{mcf}$ on the rotary. There were threeplus system shut in days resulting typically from high discharge pressure. High discharge pressure are usually due to Peake or Columbia compressor or line problems. Average discharge pressure rose significantly to $60 \mathrm{psi}$.

Test Well 1 averaged 39.8 mcf per day from the deep zones and $3.9 \mathrm{mcf}$ from the coals. The pump system had no down days and water production consistently averaged 11.6 barrels per day, as it has for several months.

TW2 averaged 8.6 mcf per day, with back pressure of 30 pounds continuing to be held on this well. TW3 averaged $10.2 \mathrm{mcf}$ per day from the Poca \#3 coal, and water production continued at its low, steady rate of 1.5 barrels per day. TW4 still showed no gas, but water production of about 50 barrels per day. It now seems apparent that we will get no gas from this well until some type of workover is performed.

Various reports were also completed during May including WV State Gas Producer Reports and a DOE Personal Property Report.

JUNE

Gas production averaged 58.6 mcf per day on the rotary master meter and 56.3 on the orifice meter. Discharge pressure averaged about 61 pounds. There were six system shut in days due primarily to high discharge resulting from Columbia compressor problems. 
TW1 averaged 37.4 mcf per day from the deep zones and 3.7 mcf from the coals. Coal gas has continually declined in recent months while water production remains steady at 11.6 barrels per day. There were no down days for the TW1 pumping system during this month.

TW2 averaged 8.0 mcf per day while back pressure was adjusted throughout the month from 12 to 25 pounds. TW3 averaged 9.0 mcf per day from the coals feeding at 9 pounds line pressure. Water production continued steady at 1.7 barrels per day. TW4 continued to make large amounts of water with no gas production.

Due to the Stop Work Order from DOE on Task 10, the remaining funds were reassigned to Tasks 12 and 13 . Therefore, an extended field work and cost plan were prepared for Task 12 during June. This plan detailed the activities and costs for workover to TW4 as first priority. These will include seismic tests, various well logs, normal well workover swabbing, and other activities. Work was also projected for each of the other Project wells.

Other miscellaneous activities during the quarter included the completion of normal monthly DOE reports, quarterly reports, tax/royalty statements, well revenue assessments, well chart integration, monthly nominations on TCO and Mountaineer systems, WV Rate Treatment documents, and monthly gas balance monitoring with Belden \& Blake. Normal field supplies were purchased during the quarter such as oil, filters, plugs, charts and other items. Finally, a Well Plugging/Salvage Summary was prepared to project the required steps and the economics of such a move, should it become necessary.

13.0 DEMONSTRATE NEWLY DEVELOPED TECHNOLOGIES FOR MULTI STRATA GAS AND WATER PRODUCTION TO ENHANCE COMMERCIAL APPLICATION

Normal operation of the dehydrator continued through the quarter. 


\section{B. MEETINGS AND TRIPS}

April 15 -- CWV/DOE Meeting as METC.

April 16, 17 -- Coalbed Methane Forums in Pittsburgh.

June 4 -- CWV Meeting with Dr. Polk, Jim Silosky, Linda Hawkins, R Brunk

June 17 -- CWV Meeting with Jim Silosky, Linda Hawkins, Ron Brunk

June 20 -- Conference Call with Charlie Byrer, Jim Weekley, Linda Hawkins, Ron Brunk

\section{PLANNED ACTIVITIES}

$>$ Acquire bids and select contractors for well workovers

$>$ Perform workover on each well

$>$ Acquire and assimilate production data in preparation for Final Report 